\title{
THE DECALOGUE IN THE NEW TESTAMENT: TRADITION, ETHOS, AND IDENTITY ${ }^{1}$
}

Jeremy Punt

Old and New Testament

Stellenbosch University

\begin{abstract}
The presence of the Torah and Decalogue in the New Testament is understandable, given their shared Jewish context; however, the manifestation and utilisation of the Decalogue in the New Testament is as ubiquitous and explicit as it is complex, multi-vocal and multivalent. In this paper two related, important aspects will be argued: firstly, the ethical notions and patterns that emerge in the New Testament, also around and in relation to the Decalogue, naturally have to be understood within their first-century context (or will not be understood at all). Secondly, rather than 'ethics', the ethos formations that can be constructed from the New Testament stand in different ways yet in close relation to emerging processes of identity negotiation discernible in New Testament texts. Considering the intersections between Torah/Decalogue, ethos and identity in the New Testament can contribute to discussions on human rights.
\end{abstract}

Key Words: Decalogue, Ethos, Identity, Jewish Tradition, Torah

\section{Introduction: Sharing in Jewish Tradition and Scriptures}

The starting point of this presentation is the Jewish nature of the New Testament. The very terms 'Jew', 'Judaism' and 'Jewishness' have in recent years led to considerable discussion regarding the validity and appropriateness of their use with regard to the first century CE, and the New Testament in particular. Even when such terms were accepted as working (if not in all respects, valid) concepts for describing a particular constellation of people in Second Temple Judaism in the first century CE, the nature, content and scope of reference of the terms were and are nevertheless the topic of many debates. ${ }^{2}$ Using a broad and maybe too simplistic grid, Jewishness is used here in connection to a shared identity built on a (not uncontested) history and (a spectrum of) social, cultural and religious traditions, and kept intact to varying degrees by claims upon a shared set of documents, the Scriptures of Israel.

The importance of the Scriptures of Israel also to communities of the early Jesus movement is evident in three critical indicators. First, the preservation of the Scriptures of Israel, presumably in Greek format, along with some other Jewish writings by the early followers of Jesus constituted a primary, assertive act of remembering (cf. Lieu 2004:75; cf. Ricoeur 1997:206), signalling the importance of the writings for the communities. Second

\footnotetext{
Paper read at an Old \& New Testament seminar, "The Decalogue, ethics and human rights", Stellenbosch, 5 November 2010.

2 The appropriateness of the use of the term 'early Christian' (and 'early Judaism') which Holmberg takes pains to defend (cf. Holmberg 2008b:3-5; cf. Runesson 2008:59-92) is hotly debated; for questions about the use of such terms such as 'Christian' or 'Judaism' in the first century, e.g. Lieu (2002:191-209; 2008).
} 
and as far as it existed, unity or at least commonality within the Jesus-follower movement was situated in and traced through myth and ethos, not through structures or leadership (cf. Telbe 2008:115-138), at least within the early years that saw the formation of early Jesusfollower communities, as attested to by the time-span of slightly more than a decade of Pauline letters. ${ }^{3}$ The relationship between the Jesus-traditions and the Scriptures in the formation of Jesus follower-identity is a third important issue. The Gospels but also other New Testament documents constantly narrated the movement's memory of Jesus through the lenses provided by Israel's Scriptures. The historical and biographical approaches in the Gospels were an attempt to connect ${ }^{4}$ and align contemporary recipients, regardless of whether they shared the traditions of Israel, with the decisive, identity-forming belonging to Jesus Christ in history. ${ }^{5}$

Amidst many other centrifugal forces at work among the authors of the documents that would become the New Testament, their Jewish nature was central for understanding their formulation and content, then and in later times. And central to the notion of Jewishness was the Torah as the first century central measure and yardstick of what being Jewish was all about. ${ }^{6}$ More than a book or collection of legal codes, or set of moral principles, or general example narratives and instructions, the Torah was seen and used as participating in the construction of an alternative reality grounded in a life in God. ${ }^{7}$

Given these broad considerations about the centrality of the Torah, and not denying differences regarding the validity and nature of its appropriation, this paper wishes to investigate the significance of the New Testament's use of the Torah and Decalogue - both

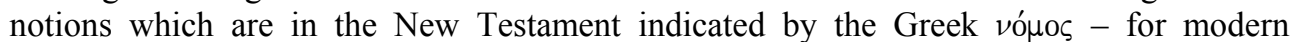
considerations of human dignity. But, the notions that the Torah was in an unproblematic way taken up in the Jesus movement or the notions that it was simply replaced (superseded) by Jesus, both disregard a multifaceted and complicated situation, which can best be addressed by moving away from notions of 'law' or legal codes to ethics and more properly, ethos. ${ }^{8}$ The first important aspect of dealing with this intricate situation is the ambiguous and often contrasting positions found on the Torah in the New Testament.

3 The seven authentic Pauline letters; the deutero-Paulines (2 Th, Col, Eph and the Pastorals) evidence a later part of the ongoing Pauline tradition(s).

4 Such connection is achieved by linking the gospel Sitz im Leben to the social memory of the groups of early Jesus-followers. According to Byrskog, it was the gospel chreia which served a mnemonic purpose, bridging past and present while contributing to the groups' sense of belonging to the past and sharing a Christ-centred identity (Byrskog 2008b:33-57).

5 However, with the increasing awareness of the (unexpressed or not reflected upon) link between the Gospels and their own, contemporary communities and of legitimating their own time through the story of Jesus, plotting the Gospel within the exploration of the construction of Christian identity through remembering the past becomes complex (Lieu 2004:87-88).

6 It is acknowledged that in the NT it is not always a simple matter to determine when vó $\mu$ o sense of Tenach, or Pentateuch, or Decalogue?

7 Even in the Pauline letters citations are predominantly from four sets of traditions or 'books' from the Scriptures of Israel; 15 citations are from Deuteronomy ( 28 from Isaiah, 20 from the Psalms, 15 from Genesis) - no other books are quoted from more than five times. Cf. Koch (1986:33) for a list of OT books from which Paul quotes, including the number he uses each of these books. Cf. Punt (1996).

8 "Ethos differs from an ethic by involving not only moral but also cultural and communal values... an ethic tells the member of a group what he or she is to do. The ethos of the group reinforces that by also saying who and where one is ...the tone and style of a group's (or culture's) entire range of values, the quality of its life" (Schütz 1976:289). 


\section{Opposing Positions on the Torah amidst Law-Pluralism}

The background for questions about the place and the role of the Torah in New Testament documents is broader than the consideration of Jewishness; suffice it to mention that contention between different laws was in the first century nothing unique, in a context where divine laws, imperial laws, city laws, and household, family, or kinship laws or moral codes often vied for the upper hand with one another. Amidst the moral crosscurrents of the first century CE, long-standing but often rival city codes and family codes clashed, and were confronted also by claims of new loyalties, issued by the empire and its accompanying and growing new cult. Even before the time of Hellenistic and Roman empires, certain laws were considered to transcend those of polis and to require obedience. ${ }^{9}$ A powerful counter current underneath the city consisted of the laws of family, although those were generally interpreted to be a subset of laws of the city ${ }^{10}$ (Meeks 1986:19-39).

As to matters Jewish, in the first century a range of different models was available for incorporating Gentiles $^{11}$ into Jewish tradition ${ }^{12}$ (Segal 1990; 1995:1-30). Apart from a fullyfledged conversion to Judaism, ${ }^{13}$ two other models existed for Gentile inclusion, those of resident sojourner ${ }^{14}$ and of the Noachide commandments, ${ }^{15}$ each with different purpose and motivation. The social impact was that resident sojourners had to observe some Jewish laws because of their close association with the Israelites, in social locations where Jews were in the majority and had political power. The reference point about the Noachide commandments was the ultimate disposition of Gentiles, presupposing that they were not law-observant, but

$9 \quad$ In the Greek drama Antigone by Sophocles, when the city-state was at its highest level of development around 400 BCE, Antigone defied the decree of her uncle Creon, who also reigned over the city, when she covered the corpse of Polynices, her brother.

10 The household, the domus, had overriding importance in the formation of a Roman's identity (Saller 1999:30-34). A larger debate in Hellenistic society concerned the tension between universal justice (by nature) and no justice by nature, the latter which made it a matter all about power, the rule of the jungle or the survival of the fittest. The idealists of the time garnered support for Roman efforts to coordinate just this utopian venture (Meeks 1986:19-39).

11 Paul's perception and presentation of the mission to Gentiles is increasingly seen against the background of a revisioned Jewish pattern of universalism, rather than of the rejection of Jewish particularism (cf. Donaldson 1994:166-193).

12 Conversion and salvation were different things in first century Judaism: the former entails the Law, the latter not necessarily as in the case of 'righteous Gentiles' (Segal 1995:5-6; cf. Boyarin 1994:299-300 n1). Firstcentury 'Christianity' was related to other Jewish groups in many ways, although probably not a Jewish 'sect' such as e.g. Pharisaism (cf. Meeks 1985:106). Through its internal diversity and notwithstanding Jewish acculturation in the Greco-Roman world, "in the long run the gentile world was marginal to the religious cosmos of virtually all Jews in antiquity" (Goldenberg 1997:99-107) - Jewish attitudes to Gentiles and their religious practices were characterised by diversity.

13 Conversion implied full observance of the Law, including circumcision (cf. also Grabbe 1994:535-536). In some hard-line Jewish groups where circumcision on the eight day was required, proselytism was impossible; cf. Jubilees 15:26-27 (Segal 1995:10-11). Donaldson suggests that proselytism is the starting point for explaining the Pauline mission and gospel according to a revisioning of Jewish universalism (1994:193).

14 Connected to biblical rules related to "the stranger in your gates", certain Jewish ceremonial and moral regulations were applicable to non-Jews in a majority Jewish community, as expressed e.g. in Lev 17:7-9; 10ff; 18:6-26; Ex 20:10f; 12:18f (Segal 1995:8).

15 This rabbinic view rests upon the sophisticated, theological claim that certain legal endorsements were given before Sinai to all human beings (Segal 1995:8-12). Various versions of Noachide commandments existed, with the first proper formulation dating back to the third century CE. However, earlier, pre-Christian versions are found in e.g. Jubilees (where they seal the condemnation of Gentiles) and Sibylline Oracles, as well as in writings by Pseudo-Phocylides and Aristeas. The commandments included the prohibition of idolatry, promiscuity and violence. 
then accommodating them as righteous Gentiles (Segal 1995:16). ${ }^{16}$ While these models are admittedly broad, with blurred borders, they do attest to the variety in Jew-Gentile relationships and the accommodation of the Torah therein.

While the New Testament documents contain evidence of tensions brought about by a pluriform (legal) context, the ambiguity regarding the presence of the Torah in the New Testament concerns two opposing positions towards it. Such ambiguity does not unsettle the centrality of the Torah among the early Jesus movement and in the New Testament documents, but it does make the situation more complex.

\section{Promoting the Torah in the New Testament: Reconfiguring?}

Positive appeals to the Torah are not difficult to find in the New Testament. Even the materials of the person often presented as the archrival of the law, Paul, can in Gal 6:2 invoke the 'law of Christ' ( the Torah in the letter as a whole, but in 5:2-6:10 in particular, and without apparent contradiction. ${ }^{17}$ Some of the strongest positive appeals to the Torah in the New Testament are found in the letter of James, which gives a particular view of how the Torah was interpreted and incorporated by the early Jesus movement. The Torah is presented as the basis for 'Christian' life, focusing on the life in Christ and showing love for the neighbour, implying a reordering of one's life.

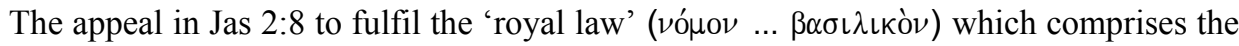

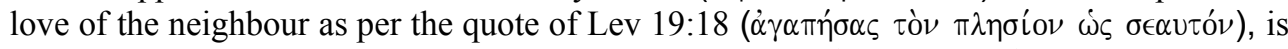

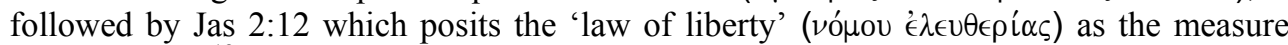
'according to ${ }^{, 18}$ which words and actions will be judged. The appeal of James for the recipients of the letter to keep or fulfil $(\tau \in \lambda \in \hat{\imath} \tau \epsilon)$ the royal law, raises the question of what is meant by keeping or fulfilling it? Did it mean simply practicing the law? But then again, which law, or should one think of only certain aspects of the law (distinguishing between ritual, ceremonial, spiritual and other uses of the law); the whole Torah or only some 'Christian' adaptation? James here probably responded to some excuse (maybe that love for neighbour requires one only to attend to the rich?), and aimed at opposing the wrong and self-indulgent use of the principle that the law of love covers the whole law. The anarthous vó $\mu$ ○ $\varsigma$ is probably due to its use as quasi-proper noun as law of God (cf. Jas 2:11;4:11). Important is that $\nu$ ó $\mu$ o $\varsigma$ here is not identical with $\gamma \rho \alpha \phi \eta$ (Scripture) and that it is not used

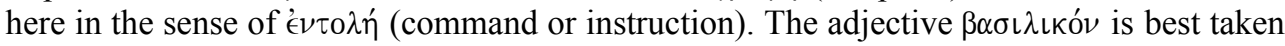
as decorative epithet, in the sense of 'supreme' in a tradition where a king is the supreme sovereign or even with reference to the Roman emperor as $\beta \alpha \sigma \iota \lambda \epsilon$ '́s. It may also be a reference to the Stoic conception of king as 'wise' (as much as the wise are free, too, cf. Jas $1: 25)$. In the end, however, 'royal' is used here most probably as decorative description; it is suggestive and not used in contrast to some other, inferior law.

For James the Torah is both the orientation and yardstick of life in Christ. Moreover, the consistently strong presence of the Torah and Decalogue, particularly in the New Testament, in explicit and sometimes in more subtle ways, is due to the Jewish roots

16 Segal points out that in such situations where the Jews lacked political power, this model avoided a potential 'backlash' from the Gentile communities' accusations against Jews 'stealing their children' (1995:17).

17 However, one also has to deal with anti-nomos statements in Paul, particularly his invectives against 'works of the Law' - in which case the importance of the NPP and the contributions of Sanders; Dunn; Ziesler; and so on are particularly important.

$18 \Delta \grave{\text { à }}$ (according to; $\mathrm{cf}$. Rm 2:12) denotes the state or condition in which one does or suffers something. 
generally shared by the authors of the New Testament and the importance of the Decalogue within Second Temple Judaism.

\section{Anti-Law Sentiments in the New Testament: Anomie?}

Such pervasive and popular appropriations of the Torah in the New Testament documents do not negate or slight the equally harsh pronunciations against the Torah. A negative attitude towards the Torah in the words of Jesus in the Gospels and also in the letters of Paul, to mention only two important reference points in the New Testament, suggests a not so uncomplicated relationship between the Torah and early Jesus followers. The effect of Jesus' consistent surpassing of the Law in the Sermon on the Mount (Mt 5-7) and strong comments from Paul that faith replaces obedience to the Law (Gal and Rom) as measure for the lives of the righteous, can create the impression that (faith in) Jesus has not only replaced the Torah but that he has in effect superseded and disempowered the Torah.

In his letter to the Galatians Paul's appeal to the experience of the audience $(3: 1-5)$ is critical for his argument. If the Galatians agree with Paul, his argument would be sound, while their disagreement would be tantamount to denying their own experience. The important point and core of Paul's argument in the letter is on the one hand that in their experience they were given life through the Spirit, mediated through the preaching of the cross and received in faith. On the other hand, Paul insists, life did not come to them through observance of the law (Johnson 1999); in fact, those who rely on works of the Law are under a curse (Gal 3:1-14), while God's promise and covenant with Abraham preceded the Torah by 430 years (Gal 3:15-20). At best the Torah can be appropriated as custodian ( $\pi \alpha\llcorner\delta \alpha \gamma \omega \gamma o ̀ \varsigma)$ until Christ's return (Gal 3:24), but even this is dangerous since the Torah enslaves (Gal 3:21-4:11). ${ }^{19}$

But rather than a consistent critical approach to it, ambiguity regarding the Torah is already evident in Paul, with for example his letter to the Romans making far more positive claims regarding the Torah, ${ }^{20}$ and given also Paul's use of Deuteronomy as one of the largest sources for his citations from the Scriptures of Israel. In this regard the New Perspective on Paul (NPP), although not without some contention and with much debate, has brought about an important corrective on the understanding of the Torah in Paul, particular as far as the understanding of the phrase 'works of the Law' is concerned. But the NPP has set in motion more than a shift from the problem with the Torah as inhibiting force with regard to salvation and imbuing a negative theology. The law can also be viewed as a potential divisive force, restricting God's grace to Jews only. Above all the NPP has forced a new interpretative context for the Torah in the Pauline letters, but also for the letters as such, shifting the focus from individualised and spiritualised readings of Paul to sociotheological readings. Rather than finding in Paul a concern with works-righteousness, his concern with the impact of a Roman imperial system of hegemony and accompanying

19 Examples of such strong tenors against the Torah in the NT can be multiplied: particularly strong is the claim in Rom 4:15 that the Torah brings wrath, and trespassing (where there is no Law there is no sin); and other strong claims against the Torah in 1 Cor 7.

20 Another specific example would be Paul's (admittedly) elliptical claim in 1 Cor 7:19 that circumcision or

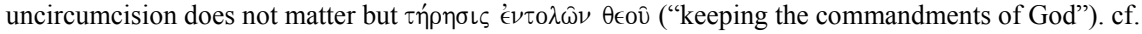
Braxton (2000:51-53). 
relationships, anchored in centuries-old hierarchies and patriarchy, is now coming into focus. ${ }^{21}$

Paul's revision of and continuity with the traditions of Israel and the Torah meant that he did not nullify the Torah, as can probably best be seen in his Spirit-led readings which treated Scripture as trope. ${ }^{22}$ In Paul's use of Scripture there are elements of revision regarding the normative significance of Torah observance (cf. Gl 6:15), operating on the periphery of the symbolic world of Israel's Scriptures. ${ }^{23}$ But in Paul there is at the same time continuity between Torah and gospel, when he for example read Scripture as a narrative of divine election and promise, with the ground of this continuity as the

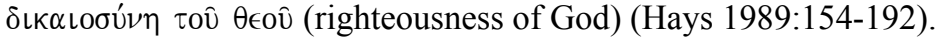

The ambiguous presence and use of the Torah in the New Testament cannot be resolved with simplistic claims to fulfilment or supersession, but require constant clarifying of sociohistorical contexts and social locations. Perhaps it is the critical tension invoked by the ambiguity surrounding the Torah that allows for the discussion of the relevance of the New Testament's portrayals of the Torah for human dignity.

\section{New Testament and Decalogue: First-Century Ethics or Ethos?}

A first question, though, is whether human dignity is an appropriate term to name and describe notions and tendencies recognised as such in current readings of the New Testament? And whether concepts such as way of life or ethos, or some such more general terms should not be used? The danger of importing values and 'baggage' belonging to modernist ideas sourced from humanist tradition ${ }^{24}$ looms large, ascribing and connoting (if not at times also denoting) values and norms derived from ancient texts, cast in traditions formed through and around hierarchies, patriarchy, patronage, honour and shame and so forth? Are concessions to the conventions of the time, the adjustments in structures, systems and thinking indicative of transformation, or of radical disjuncture, or rather of reestablishment or reinforcement? Such questions can be addressed for example by looking at how the New Testament authors made use of the Decalogue in formulating the identity of communities, but also how the Decalogue was used to prop up power and control.

To already anticipate the conclusion of my argument, the role of the Decalogue in formulating the ethics but even more, in contributing to the formation of the ethos or life in its different dimensions pertaining to the new lifestyle of the followers of Jesus, can hardly be overrated. ${ }^{25}$ However, claiming the importance of the Torah is not tantamount to its

21 Many questions of ambiguity in the use of the Torah in the NT cannot be discussed here, such as the interesting question about the re-appropriation of the Torah in $1 \mathrm{Pt}$ although these documents are often thought to harbour some sort of link to or relation with the Pauline materials?

22 Marks (1984:71-92) argues that Paul's spiritual autonomy prompted his ambivalence, and that Paul was not an apologist (dependent on Scriptures for legitimating his authority) but a dogmatist (affirming the priority of own position by imposing them on earlier tradition).

23 Paul never lost interest in the history of the Jews or the world, but to the contrary, his apocalyptic hermeneutic made the fate of the world and Israel (Rom 8 and 9-11) very important. Rather than asserting his individual autonomy against Israel's tradition, Paul found himself amidst a strange anachronism, a dialectical struggle to maintain the integrity of own proclamation re Scripture, and the integrity of Scripture re his proclamation (Hays 1989:154-192).

24 The humanist project, whether or not in religious guise, was not neutral, but a powerful tool of imperialism. In Africa, humanism was used for colonising the minds of African students for within it "bourgeois Europe was always at the center of the universe" (Ngugi 1986:17; cf. Dube 1996:41).

25 Brooks refers to "the Jewish law as a category, the purveyor of morality and ethics, as well as deep spirituality, but thoroughly expressed in the legal details of day to day practice" (Brooks 1990:ix). Although 
simplistic invocation in the New Testament, or considering the nature of the Torah in the New Testament to be a straightforward matter - so the rest of the contribution sets out to explain the claimed importance of the Torah in the New Testament and the consideration of human dignity.

\section{Torah and/as Ethics in the New Testament?}

One, whether it is a matter of morals or more, even a cursory investigation of the Torah in the New Testament, shows that most often the presence and impact of the Decalogue within and upon New Testament writings were discussed from the perspective of morality and ethics (e.g. Shrage 1982; Verhey 1984). Indeed, ethicists would further expand on such work, and invoked categories such as deontological, utilitarian, thaumaturgical and so forth in an attempt to identity, classify and systematise 'New Testament ethics'. ${ }^{26}$ My contention is that such approaches to New Testament ethics, as hinted above and argued (to some extent) below, are insufficient and in many instances even inappropriate, certainly for accounting for the Torah in the New Testament.

Second, the investigation of the Torah in the New Testament in a discussion about human dignity, requires attention for the specific content of the Torah where and as it is encountered, and simultaneously to consider the nature of its invocation. Indeed, attention is required for example for what and how appeals were made to the Decalogue in the New Testament; and whether such appeals were meant to reinforce or subvert or even reinvent the Decalogue? One difficulty, that of determining and understanding the nature of Old Testament-generated New Testament ethics, such as in the hyperboles of Mt 5-7 and in the love patriarchalism in the Fourth Gospel, to name a few, is evident. A further difficulty is to explain the connections between the Jewish originating ethics and other ethical frameworks deriving from a Hellenistic context or gleaned from imperial codes, such as the Haustafeln of Eph 5-6; Col 3; $1 \mathrm{Tm}$; and also 1 Pt 2-3. ${ }^{27}$

To find adequate terms to describe and frameworks to interpret how the Torah is taken up but also expanded in the New Testament, is an important but not a simple task. ${ }^{28}$ Breaking with the notion that the discussion of the Torah in the New Testament is primarily a matter of ethics and a monolithic enterprise at that, is an important first step; a second step is to see the Torah's function in the New Testament in relation to ethos.

Brooks tend to evaluate the Torah and Decalogue from the position of Rabbinic Judaism, dated post-New Testament times, the prevailing sentiments about the Torah and Decalogue among insiders were probably not that different in the different settings.

26 An important sub-section of work on the Decalogue and ethics includes research to establish which parts of the Decalogue were used prominently in the NT, and to formulate acceptable hypotheses in this regard - such investigation lies beyond the scope of this contribution.

27 The gendering of ethics in the New Testament was in line with the gender-biased first-century societies, and the New Testament texts show some early signs of the tendency of the early Christian Church of the second and later centuries. "[T]he ancient Christian rhetoric of shame routinely - and paradoxically - exhorted both sexes to become more 'manly' through the adoption of a 'feminine' standard of conduct" (Clark 1991:222, emphasis in the original). A few instances of a rhetoric of shame is found in the New Testament (e.g. Mk 8:38 // Lk 9:26; Mt 5:47; 1 Cor 1:27; 4:8-13; 5:1-2), but did not inform the dominant ethical discourse in the New Testament (Clark 1991:222).

28 Also in the early Christian literature, e.g. the Didache (cf. Lieu 2004:89). 


\section{Role of the Torah in the emerging New Testament Ethos}

Ethos is always a situated and socially located notion; it never exists an sich, it never just 'is'. Ethos is always carefully constructed, informed, qualified and determined by a variety of different notions: spatially and temporally, culturally and politically, socially and environmentally and so forth. Such construction is often, but not necessarily, overt and conscious, rendering the ethos of a community as a pervasive notion informing life in multiple and constructive ways.

Therefore, in the interplay of Decalogue, ethics and human rights another important set of questions has to be addressed: to account for how the Decalogue was used in identity politics, to frame a certain ethos; and to understand the power and force exerted through appeals to the Decalogue, and the contexts and agencies involved. While the discussion up to this point painted with a broad brush in reference to the Torah, from this point the focus shifts somewhat more towards the Decalogue. And the juxtaposition of ethos, social location and Decalogue with regard to the New Testament documents immediately give rise to a further range of questions. ${ }^{29}$

Can issues about the appropriate acknowledgement and worship of God be seen as disconnected from socio-cultural matters such as patronage and kinship? How are the notions of theft and desire to be understood in a collectivist culture, where kinship ruled relationships, order of birth determined status and wealth of children, and both the economic and social worlds were inseparably bound up with pervasive, institutionalised slavery? What would inform the concept of adultery in a patriarchal world where women had neither voice nor legal person, where slaves were in all ways also sexually available to their mostly male owners? ${ }^{30}$ Can love for the neighbour (Lev 19:18 in e.g. Gal 5:14; Rom 13:8-10; Jas 2:8) be understood without accounting for first-century concerns about kinship, friendship, hospitality, etc? Claims that in first-century Christian communities none of these historical, socially-determined conventions and customs were present, or that they were simply set aside by some generally accepted 'Christian ethics' which approximated twentieth first-century styled bills of human rights, are countered by the New Testament texts which in various and different ways, and not always to the same extent, are testimony precisely to these contemporary social customs and conventions.

In the end, the Decalogue's use and impact in the New Testament and the formation of a new Christ-focused ethos have to be considered against the identity politics that governed the context of the emerging Jesus movement.

\section{New Testament, the Decalogue and Identity}

Notwithstanding the importance and even ultimacy that Paul in the earliest documents of the New Testament attached to the coming of Jesus and his death and resurrection, in particular, for grounding his understanding of the Gospel, or his knowledge of and regard for at least some Jesus traditions, these traditions did not occupy the same place nor exhibit the same intensity as the Scriptures of Israel. "More important for Christian identity, then,

29 In a related way, it is interesting to note how in the later Rabbinic tradition, much emphasis was put on the flexibility of and innovation in interpretations of the Torah, which were in no way seen to deprive the Torah of either its authority or its relevance (cf. Brook 1990:18-27).

30 For more on the gendered ethos found in the NT, cf. Clark (1991).

31 Although focusing more on the NT Gospel traditions, Kelber (2006:15-22) rightly bemoans the disregard for memory in NT studies. However, he appears to gloss over the involvement of the Scriptures both in giving memory content (or 'cold memory' as he would probably refer to it, Kelber 2006:16) but also in continuous 
was this prior history that found its climax in Jesus than any subsequent one that took its start from him" (Lieu 2004:94). For Paul, neither did the Jesus narratives or traditions provide a history, nor did Paul use them as foundational in his letters. ${ }^{32}$ The reformulated, the metamorphosed lifestyle was of course not only about a certain code or codes of rules and regulations; as much as other religious formations and groups also lived according to certain agreed-upon codes for communal and individual morality (of which Second Temple Judaism is often offered as good example; cf. Cohen 1987), such practices were interwoven with interesting and complex identity negotiation processes.

The importance of the Decalogue in the New Testament is confirmed when its prevailing presence is compared, apart from the Gospels, ${ }^{33}$ with the relatively scarce referencing to Jesus traditions in canonical and deutero-canonical texts. Certain elements of the Decalogue and more broadly the Torah are often included, through explicit scriptural or dominical appeal, in the construction and formulation of new moral rules. While the formulation of a distinctive post-70 CE morality or even moral identity often relates to synoptic Jesus traditions, legitimation for it is not sought through its ascription to Jesus. ${ }^{34}$ Even when Didache 4:13 calls upon its readers to "See that you do not neglect the commandments of the Lord, but keep them just as you received them", an echo with Deut 4:2 springs to mind rather than a specific set of utterances of Jesus Christ (Lieu 2004:89).

Perhaps the best example of the priority of Israel's traditions of the past over the Jesus traditions is found enacted in the initial limited impact of Acts. Acts is evidently apologetic historiography intent on negotiating a certain identity for a minority group within a wider culture, and structures this identity by showing the continuity between the history of Israel and the narrative of Jesus. However, not only are Acts' consistent attempts at showing continuity between the Jesus traditions and the ongoing story of his followers not followed through with similar intensity in the rest of the New Testament, but it took another almost 200 years for Eusebius to attempt a Christian history in the middle of the third century. On the one hand, during the time of the formation of the New Testament the prior history of Israel, complete with Jesus portrayed as its climax, was far more important for the formation of the early Jesus-follower identity than subsequent traditions that claimed to originate from him (Lieu 2004:94). On the other hand, the New Testament provides evidence of how Israel's Scriptures and traditions, and also the Torah and Decalogue were reconfigured.

negotiation of understanding the life and significance of Jesus, as well as providing a hermeneutical map for such understanding. Rather than claiming that "the Jesus tradition commenced not with archives, but from remembering" (Kelber 2006:18), it is probably more accurate to argue that the tradition was invoked and remembered in conjunction with textual archives, also!

32 With the possible exception of 1 Cor 11:23-26! This tendency would reach well into the second century, with Apostolic Fathers and Apologists showing a relative lack of interest in the life of Jesus as found in the synoptic Jesus traditions; Lieu (2004:89) also refers to the moral traditions found in the Didache which connects far more strongly with the Torah than the Jesus traditions. The exception in the NT is the Acts of the Apostles, stressing continuity between Jesus and the later church. Keightley (2005:129-150) argues that Paul's familiarity to the Jesus traditions can be traced primarily to his participation in rituals of the early followers of Jesus.

33 And possibly the Acts of the Apostles: in the prologue (Ac 1:1-2) the continuity with what Jesus "began to

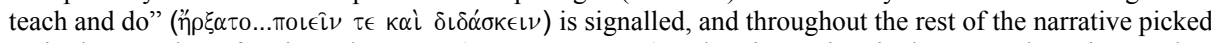
up in the speeches of various characters (e.g. Ac 10:36-43) and various mimetic themes such as signs and wonders, Peter's raising of Tabitha, Stephan's dying vision and words (e.g. 3:1-10; 9:36-43; 7:58-70) (Lieu 2004:90).

34 Some other examples are found in Didache 1-5, while moral rules about turning the other cheek are found together with instructions not to commit murder, adultery, theft and so on (Did 1:4; 2:2; cf. Lieu 2004:89). 


\section{The Torah and Decalogue reconfigured: Freedom}

In the Pauline corpus, Galatians is the best example where Paul both waxes lyrical about freedom achieved by, through and in Christ, while at the same time presenting what appears to be condemning arguments against the Torah. While Paul's focus on freedom is undergirded by references to the cross of Jesus, as well as to a life in the Spirit, in his argument the antagonism against the Torah is palpable: it is the very Torah (Deut 21:22-23) that cursed and therefore condemned Jesus on the cross. Following through on his argument, Paul argues for an uneven position between Jesus and the law since he died under the law's curse, and that the law cannot condemn or make further claims on a person who shares in the crucifixion of Christ". ${ }^{35}$ Paul's argument is somewhat more complex than simply dismissing the Torah because Christ was crucified, but the connection between a negative position on the Torah and Christ crucifixion is difficult to deny in Galatians. ${ }^{36}$

Freedom for Paul in the second place rests on life in the Spirit, connected with the notion of union with Jesus Christ. In short, the freedom wrought by Christ is not only a 'negative freedom', freedom from death, sin and flesh, and the law, but is also a 'positive' or constructive freedom: freedom to love, to hope, to be of service to one's neighbour as much as one is subject to Christ. ${ }^{37}$ Rather than thinking of the Spirit as empowering obedience to Law, Paul argues that to be led by the Spirit means no longer to be under the Law (Gal 5:18). In a different role, the Torah as $\pi \alpha\llcorner\delta \alpha \gamma \omega \gamma o$ ó (disciplinarian, Gal 3:24-25) could only present objective moral standards rather than subjective moral transformation; where directive power of law fails, the Spirit succeeds. From union with Christ and a life in the Spirit flows love as an empowering notion. ${ }^{38}$ Not only did Paul receive the revelation of God's son (Gal 1:16), but in so doing also received the revelation of love, which transformed Paul's life. The nature of such love was defined by the self-sacrificing love of Christ (Gal 1:4; 2:20; 3:13; 4:4-5), and since faith in Christ expresses itself through love, the central task of Pauline ethics is about the call for living out (of) Christ-like love?

It is at this point that the paradox of keeping and not keeping the Torah is found. Apart from another paradox of love, claiming freedom as slaves of Christ, ${ }^{39}$ Paul insists on the one hand that it is not an obligation to keep the law (Gal 5:3) but on the other hand calls on the Galatians to fulfil the law in loving their neighbours (Gal 5:14). The paradox cannot be explained by appeals to distinguish between justification and sanctification, or between ceremonial and moral laws, or even with reference to the possible ethnic use of the law.

35 Paul described his own conversion as apocalyptic experience, as the end of the world of the old order, since he identified with cross (Gal 6:14).

36 The Torah fostered competition and made 'works of the law' to be 'works of the flesh' (cf. Gal 5:19-21 re social breakdown e.g. enmities, strife, etc.). The Judaisers were not keeping it themselves: their campaign to bring Gentile followers of Jesus into submission to the law resulted in their breaking the law by boasting in the flesh.

37 "The goal for which the Christian is set free is subjection to God in Christ" Malina (1978:70). This is indeed why Paul can offer slavery as a predetermined choice for a follower of Christ. To be a slave of Christ or a slave of obedience implies a religious act or decision. Wilder calls the 'pressure of Christian freedom' the imperative of love and suffering (Wilder 1961:415-416). Conley (1977:21), however, argues that the idea of 'freedom to' is a relatively recent concern of philosophers; 'freedom from' is more classical.

38 Expressing the content of love as displayed in cross of Christ is the shape of love, while the appropriate moral power to love as it is provided in the Spirit, is the strength to love (Hansen 1997:236).

39 Malina finds the origin of the idea of becoming a slave for God, of rendering service to God, in the LXX, e.g. Judg 10:13,16; Ps 2:11; 99:2; 101:23 (Malina 1978:72). Slave service to God could entail three notions: it is rooted in justice, peace and joy in the Spirit but does not consist in these qualities; it is directed to Christ; and, it consists essentially in treating one's neighbour according to the demands of agape (Malina 1978:72). Cf. Brooks (1990) on 'the spirit' of the Ten Commandments. 
The paradox is probably better understood as raising the difference between 'doing law' and 'fulfilling law', where the law does not prescribe but describes so that fulfilling the whole law becomes the result of expressing Christ self-giving love. Furthermore, the law which Paul required the fulfilment of was not the 'whole law' but the 'law of Christ'. While the law of Christ is intent on restoring sinners and bearing their burdens (Gal 6:1-2), the Mosaic Law points out transgressions (Gal 3:19). ${ }^{40}$

In Paul's reasoning, the obvious parallel between the two laws is situated in their commands to render mutual service, but the two are not identical, partly at least because some laws were deemed not applicable to Gentile believers. Going beyond the command to love, the law of Christ was defined and applied in terms of external principles and specific directives. Paul's insistence on the law of Christ is thus not about the replacing of one legal code with another, but refocusing from the earthly life of Jesus to his cross. The cross sets the standard for self-giving, for self-sacrificing love, ${ }^{41}$ enabled and led by the Spirit (Hansen 1997:213-237). ${ }^{42}$

A final consideration threatening to upset a constructive view on and use of the Torah in the New Testament is its cooptation in claims to authority and the exercise of power. Ambiguity is at work here too. The Decalogue is invoked in subtle ways to inform but also sanction various New Testament authors' requirements for a life in Christ. ${ }^{43}$ However, and notwithstanding the rhetorical power of an appeal to ancient traditions, an author such as Paul, who often cited the Scriptures, did not employ them as authorities for settling disputes (cf. Punt 1996). In practice, when in Rom 13, Gal 6 and Jas 2 the text of Lev 19:18 to love the neighbour is cited, it functions as an ethical appeal in itself, but simultaneously also forms the basis of the subsequent moral and ethical instructions (in each of the three cases). It even functions as the grounding for the ethos of the communities at once addressed and constructed through these documents.

\section{Conclusion}

It is probably a bit too much and too unqualified to claim that "The Ten Commandments, the record of God's most basic guidance to the Israelite nation, undergird the JudeoChristian tradition of law and ethics" (Brooks 1990:1). As suggested earlier, my conclusion is that the role of the Decalogue in formulating ethics and in contributing to the formation of the ethos in the New Testament document is pervasive if, however, contested. Some of the best potential for the use of the New Testament's appropriation of the Decalogue in human dignity discussion is probably situated in the connections made between the

40 In Gal 5:22-23 Paul expanded on the qualities of the character produced by the Spirit. The fruit of the Spirit resonates with ancient biblical prophecies of the fruitfulness of Israel through the Spirit's outpouring (e.g. Is 32:15-16; Joel 2:18-32). For Paul, the law cannot produce moral fruit (Gal 3:21) like the Spirit. In his description of these moral qualities, Paul used the general standards of popular Hellenistic philosophers rather than a distinctive 'Christian' ethic (Hansen 1997:222).

41 The Bible can serve in this way as 'magna carta' for human rights (Soares-Prabhu 1995:85-96; cf. Marshall 1997:74ff) in the double sense of affirmation of human dignity and co-responsibility, where, in the case of the latter, the "obligations of the strong towards the weak constitute the proper divine order".

42 Contemporary philosophers on Paul and law find value in Paul's use of the Law as 'justice' (cf. Jennings 2009). The major shortcomings of the contemporary European philosophical 'run' on Paul (by authors such as Agamben and Badiou) manifest both in sense of continuing FC Baur/Walter Bauer line (cf. in Holmberg 2008) of Christian universalism vs Jewish particularism, as well as in terms of anti-Judaic and even antiSemitic consequences.

43 So e.g. Castelli (1991) has argued that Paul's appeal to imitation ( $\left.\mu \iota \eta \sigma^{\prime} \iota \varsigma\right)$ is an exercise in power; and, Polaski (1999:esp 104-123) has shown how Paul invoked the notion of grace ( $\chi \alpha \dot{\rho} \rho \varsigma)$ to exert authority. 
Decalogue and ethos, as well as the identity of the emerging Jesus movement. In the appropriation of the Decalogue it is the strong emphasis on both love and freedom in the New Testament as characteristics of a life in Christ, that gives both new impetus to the continuing relevance of the Decalogue, as well as suggestions of how its relevance was (and can be) reconfigured and taken up - also in discussions about human dignity.

\section{BIBLIOGRAPHY}

Boyarin, D 1994. A Radical Jew. Paul and the Politics of Identity. Critical Studies in Jewish Literature, Culture, and Society, vol 1. Berkeley: University of California Press.

Braxton, BR 2000. The Tyranny of Resolution: 1 Corinthians 7:17-24. SBL Dissertation Series, vol. 181. SBL: Atlanta.

Brooks, R 1990. The Spirit of the Ten Commandments. Shattering the Myth of Rabbinic Legalism. San Francisco: Harper \& Row.

Burridge, RA 2007. Imitating Jesus. An Inclusive Approach to New Testament Ethics. Grand Rapids: Eerdmans.

Clark, EA 1991. Sex, Shame, and Rhetoric: Engendering Early Christian Ethics. Journal of the American Academy of Religion 59(2):221-45.

Cohen, SJD 1987. From the Maccabees to the Mishnah. Library of Early Christianity, (ed.) WA Meeks. Philadelphia: Westminster.

Conley, T 1977. Response. In Paul's Concept of Freedom in the Context of Hellenistic Discussions about the Possibilities of Human Freedom, (ed.) W Wuellner, 19-22. The Center for Hermeneutical Studies in Hellenistic and Modern culture, Protocol of the 26th Colloquy.

Davids, P 1982. Commentary on James. NIGTC. Grand Rapids. Eerdmans

Donaldson, TL 1994. "The Gospel that I Proclaim among the Gentiles" (Gal 2.2):Universalistic or Israel-Centred? In Gospel in Paul. Studies on Corinthians, Galatians and Romans for Richard N Longenecker, 166-193. JSNT Supplement Series, vol 108. Sheffield: Sheffield Academic Press.

Dube, MW 1996. Reading for decolonization (John 4:1-42). Semeia 75:37-59.

Gerhardsson, B 1981. The Ethos of the Bible, trans. S Westerhom. Philadelphia: Fortress.

Goldenberg, R 1997. The Nations that Know Thee not. Ancient Jewish Attitudes towards Other Religions. Biblical Seminar, vol 52. Sheffield: Sheffield Academic Press.

Grabbe, LL. 1994. Judaism from Cyrus to Hadrian. London: SCM.

Hansen, GW 1997. Paul's Conversion and his Ethic of Freedom in Galatians. In The road from Damascus. The impact of Paul's conversion on his life, thought, and ministry, (ed.) Longenecker, RN, 213-237. Grand Rapids: Eerdmans.

Harrelson, W 1980. The Ten Commandments and Human Rights. Overtures to Biblical Theology, vol. 8. Philapdelphia: Fortress.

Hays, RB 1989. Echoes of Scripture in the letters of Paul. New Haven \& London: Yale University Press.

Holmberg, B 2008b. Understanding the First Hundred Years of Christian Identity. In Exploring Early Christian Identity, (ed.) B Holmberg, 1-32. Wissenschaftliche Untersuchungen zum Neuen Testament, vol. 226. Tübingen: Mohr Siebeck. 
Jennings Jr, TW 2009. Paul against Empire: Then and Now. In The Bible and the Hermeneutics of Liberation, eds. AF Botta, and PR Andiñach, 147-67. Semeia Studies, vol. 59. Atlanta: SBL.

Johnson, Luke T 1999. The writings of the New Testament. An interpretation. Rev. (ed.) Philadelphia: Fortress.

Keightley, GM 2005. Christian Collective Memory and Paul's Knowledge of Jesus. In Memory, Tradition, and Text. Uses of the Past in Early Christianity, 129-50. Semeia Studies, vol. 52. Atlanta: SBL.

Kelber, W 2006. The Generative Force of Memory: Early Christian Traditions as Processes of Remembering. Biblical Theology Bulletin 36(1):5-22.

Koch, D 1986. Die Schrift als Zeuge des Evangeliums. Untersuchungen zur Verwendung und zum Verständnis der Schrift bei Paulus. Beiträge zur historische Theologie, vol. 69, (ed.) Wallman, J. Tübingen: JCB Mohr (Paul Siebeck).

Lieu, JM 2002. Neither Jew nor Greek. Constructing Early Christianity. Studies of the New Testament and Its World. London: T \& T Clark.

Lieu, JM 2004. Christian Identity in the Jewish and Graeco-Roman World. Oxford: Oxford University Press.

Malina, BJ 1978. Freedom: A Theological Enquiry into the Dimensions of a Symbol. BTB 8:62-76.

Marks, H 1984. Pauline Typology and Revisionary Criticism. Journal of the American Academy of Religion 52(1):71-92.

Marshall, PA 1997. Religious Toleration and Human Rights. In Should God get tenure? Essays on Religion and Higher Education, (ed.) Gill, DW, 74-85. Grand Rapids: Eerdmans.

Maynard-Reid, PU 1987. Poverty and wealth in James. Orbis: Maryknoll.

Meeks, WA 1985. Breaking Away: Three New Testament Pictures of Christianity's Separation from the Jewish Communities. In "To See Ourselves as Others See Us": Christians, Jews, "Others" in Late Antiquity, eds. J Neusner and ES Frerichs, 93-115. Chico: Scholars.

Meeks, WA 1986. The moral world of the first Christians. Library of Early Christianity. Philadelphia: Westminster.

Ngugi wa Thiongo 1986. Decolonising the Mind: The Politics of Language in African Literature. London: James Curry.

Punt, J. 1996 Paul, Hermeneutics and the Scriptures of Israel. Neotestamentica 30(2):377-425.

Ropes, JH 1978. The epistle of St James. ICC. Edinburgh: T\&T Clark.

Ricoeur, P 1997. The Self in the Mirror of the Scriptures. In The Whole and Divided Self, (eds.) DE Aune, and J McCarthy, 201-20. New York: Crossroad.

Runesson, A 2008. Inventing Christian Identity: Paul, Ignatius, and Theodosius I. In Exploring Early Christian Identity, (ed.) B Holmberg, 59-92. Wissenschaftliche Untersuchungen zum Neuen Testament, vol. 226. Tübingen: Mohr Siebeck.

Saller, RP 1999. Roman Kinship: Structure and Sentiment. In The Roman Family in Italy. Status, Sentiment, Space, eds. B Rawson and P Weaver, 7-34. Canberra, Oxford: Humanities Research Centre, Clarendon. 
Schrage, W 1982. Ethik des Neuen Testaments. Grundrisse zum Neuen Testament, vol. 4, (ed.) G Friedrich. Göttingen: Vandenhoeck \& Ruprecht.

Schütz, JH 1976. Ethos of Early Christianity. In Interpreter's Dictionary of the Bible, Supplemental vol, (ed.) Buttrick, G, 289-293.

Segal, AF 1990. Paul the Convert. The Apostolate and Apostacy of Saul the Pharisee. New Haven: Yale University Press.

Segal, AF 1995. Universalism in Judaism and Christianity. In Paul in His Hellenistic Context, (ed.) T Engberg-Pedersen, 1-29. Minneapolis: Fortress.

Soares-Prabhu, GM 1995. The Bible as Magna Carta of Movements for Liberation and Human Rights. Concilium 1995/1:85-96.

Telbe, M 2008. The Prototypical Christ-Believer: Early Christian Identity Formation in Ephesus. In Exploring Early Christian Identity, (ed.) B Holmberg, 115-38. Wissenschaftliche Untersuchungen zum Neuen Testament, vol. 226. Tübingen: Mohr Siebeck.

Verhey, A 1984. The Great Reversal. Ethics and the New Testament. Grand Rapids: Eerdmans.

Wilder, AN 1961. Eleutheria in the New Testament and Religious Liberty. Ecumenical Review 13(4):409-420. 